\title{
Residual Concentration of PAHs in Seafood from Hormozgan Province, Iran: Human Health Risk Assessment for Urban Population
}

\author{
Seyedeh Laili Mohebbi Nozar, Wan Ruslan Ismail, and Mohamad Pauzi Zakaria
}

\begin{abstract}
This study is to determine the concentrations of sixteen poly aromatic hydrocarbons in eighteen pooled samples of fish, shrimp, crab and bivalve from markets of Hormozgan province, Iran. The poly aromatic hydrocarbon levels varied from $16 \pm 8.4$ to $28.18 \pm 3.74 \mathrm{ng} / \mathrm{g}$ wet weight. The investigated samples were classified as minimally contaminated. Distribution patterns showed that PAHs with 4, 5 and 6 rings dominated, confirming the pyrogenic source of detected PAHs. Fish contributed more than other biota groups in transforming of PAHs to Hormozgan Province people. The average of B (a) $P_{\text {eq) }}$ values for the studied biota was $2.71 \pm 2.28 \mathrm{ng} / \mathrm{g}$ that was greater than calculated local screen value. This finding was implemented in poor quality of studied biota and necessity for risk management.
\end{abstract}

Index Terms-Hormozgan Province, PAH, risk assessment, seafood.

\section{INTRODUCTION}

Poly aromatic Hydrocarbons (PAHs) are a large group of lipophilic chemicals [1] with wide environmental distribution [2]. PAHs have been originated from diverse sources, including of the pyrolytic process such as incomplete combustion of organic chemicals [3], [4], land-based sources [5], drilling operation [6] and high contribution of activities related to petroleum industry [7]. US Environmental Protection Agency established a list of sixteen PAHs named as "16 EPA PAHs" [8]. Many of the adverse biological effects are reported for EPA PAHs [9].

Hormozgan Province in south of Iran, is bordered by the Persian Gulf and Gulf of Oman. This strategic province covers the Hormoz Strait with the vital importance in oil exporting. In addition to this, many of the industries have been established along the coastal lines of Hormozgan Province which resulted in release of untreated or imperfect treated urban and industrial wastewater in marine environment. There are no published studies related to human risk assessment from organic pollutants such as PAHs through consuming fish and seafood in southern parts of Iran. The objective of this study was to determine the levels of PAHs in commercial fish and seafood in order to assess the

Manuscript received March 4, 2013; revised May 2, 2013. This work was supported by the Persian Gulf and Oman Sea Ecological Research Institute, Bandar Abbas city, Iran.

Seyedeh Laili Mohebbi Nozar is with the Center for Marine and Coastal Studies (CEMACS), Universiti Sains Malaysia, 11800 Minden, Penang, Malaysia (e-mail: lmohebbi@yahoo.com).

Wan Ruslan Ismail is with the Center for Marine and Coastal Studies (CEMACS), and School of Humanities, Universiti Sains Malaysia, 11800 Minden, Penang, Malaysia (e-mail: wruslan@usm.my).

Mohamad Pauzi Zakaria is with the Faculty of Science and Environmental Studies, Universiti Putra Malaysia, Serdang 43400, Selangor, Malaysia (e-mail: drpauzi@gmail.com). exposure of Hormozgan Province consumers.

\section{MATERIALS AND METHODS}

\section{A. Sampling}

The common seafood samples which includes fish, shrimp, crab and bivalve, were purchased from fish markets of Hormozgan province between October 2010 and May 2011. The edible parts of collected samples were dissected. Muscle tissues without skin and bone for big size fish, for small size fish the whole edible part and for shrimp, crab and bivalve, the soft bodies were chosen. Three pooled samples for each species were prepared by mixing the transacted parts from at a minimum three numbered individuals or $1,000 \mathrm{~g}$ for bivalve. Samples were kept at $-20{ }^{\circ} \mathrm{C}$ until PAHs analysis.

\section{B. PAHs Extraction/Instrumental Analysis}

Analyzed PAHs included naphthalene (NA), acenaphthylene (ACY), anthracene (AN), fluoranthene (FLA), pyrene (PY), benz[a]anthracene (BaA), chrysene $(\mathrm{CHR})$, benzo[b]fluoranthene $(\mathrm{BbF})$, benzo[k]fluoranthene $(\mathrm{BkF})$, benzo[a]pyrene (BaP), dibenz[a,h]anthracene (DahA), benzo[ghi]perylene (BghiP), indeno[1,2,3-cd]pyrene (IcdP).

The determination of sixteen EPA PAHs was performed based on microwave extraction [10]. Mixture of about 2-5 g of freeze-dried and smashed sample with methanol was exposed to microwave radiation for 20 minutes at $115^{\circ} \mathrm{C}$. Saponification of lipids was performed with addition of $\mathrm{KOH}$ and radiation of microwave waves for 10 minimums at $90{ }^{\circ} \mathrm{C}$. Clean up and fractionation of extract was performed using silica/alumina column. PAHs were analyzed on a capillary column of DB-5ms in gas chromatography system equipped with a mass selective detector. Injector temperature was kept at $290{ }^{\circ} \mathrm{C}$. Column temperature program started from $60{ }^{\circ} \mathrm{C}$ ( 1 min hold) and increased to $100{ }^{\circ} \mathrm{C}$ (with $10{ }^{\circ} / \mathrm{min}$ ramp) and finally to $300{ }^{\circ} \mathrm{C}$ (with $4{ }^{\circ} \mathrm{C} / \mathrm{min} \mathrm{ramp}$ ) and was maintained for 15 minutes . Helium was used as carrier gas at $1.5 \mathrm{ml} / \mathrm{min}$. Single ion monitoring mode was used at 128 , $152,154,166,178,202,228,252,276$, and $278 \mathrm{~m} / \mathrm{z}$.

\section{Quality Control}

With each set of samples, method blanks were run to investigate the possibility of contamination peaks at monitoring ions. To assess the precision of the analytical methods, three duplications of all experiments were performed. The accuracy of analytical methods was inspected through matrix spike technique with surrogate standards. Totally, by using the certified reference material IAEA-406 for fish homogenate, the quality assurance of the procedure was confirmed. The calculated method detection limit and recoveries were $0.5-0.7(\mathrm{ng} / \mathrm{g})$ and $85-115$ respectively. 


\section{Calculation of Screening Value}

The screening value for carcinogenic effect of PAHs was calculated based on the following equation [11]:

$$
S V=[(R L / C S F) \times B W] / C R
$$

where

BW body weight $(73 \mathrm{~kg})$

CR consumption rate $(55.1 \mathrm{~g} / \mathrm{d})$

CSF oral cancer slope factor (7.3)

RL maximum acceptable risk level ( 0.00001)

The information regarding average body weight and daily consumption of seafood were provided by Hormozgan University of Medical Science and Hormozgan Fishery Office respectively.

\section{E. Calculation of $B[a] P$ Equivalent}

$\mathrm{B}$ [a] $\mathrm{P}$ equivalents of PAHs were determined based on toxic equivalent factors (TEFs) provided by Nisbet and LaGoy (Table I) [12].

\section{F. Determination of Dietary Intakes}

Dietary intakes of PAHs were determined based on following equation:

Dietary intakes $=P A H$ concentration $\times$ consumption rate
TABLE I: TOXIC EQUIVALENCY FACTORS FOR INDIVIDUAL PAHS

\begin{tabular}{llll}
\hline Name & TEF & Name & TEF \\
\hline Naphthalene & 0.001 & Benzo[a]anthracene & 0.1 \\
Acenaphthylene & 0.001 & Chrysene & 0.01 \\
Acenaphthene & 0.001 & Benzo[b]fluoranthene & 0.1 \\
Fluorene & 0.001 & Benzo[k]fluoranthene & 0.1 \\
Phenanthrene & 0.001 & Benzo[a]pyrene & 1 \\
Anthracene & 0.01 & Indeno[1,2,3-cd]pyrene & 0.1 \\
Fluoranthene & 0.001 & Dibenzo[ah]anthracene & 1 \\
Pyrene & 0.001 & Benzoghi]perylene & 0.01 \\
\hline
\end{tabular}

\section{RESULTS}

\section{A. PAHs Concentration and Distribution Pattern}

Average levels of $\sum$ PAHs (ng/g wet weight) in seafood samples are represented in Table II. Concentrations were varied from $16 \pm 8.4$ to $28.18 \pm 3.74 \mathrm{ng} / \mathrm{g}$ wet weight. The lowest and highest levels were related to Grunt and Banana Shrimp, respectively. Totally, the detected average of $\sum$ PAHs for the tested biota was $20.9 \pm 7.42 \mathrm{ng} / \mathrm{g}$ wet weight.

The abundance of PAH components in terms of ring number are shown in Fig.1. The percentages of PAHs abundance for $2+3,4$ and $5+6$ rings were $39.3 \pm 12.8,24.29 \pm$ 15.24 and $36.41 \pm 19.82$, respectively. The mean values of $\mathrm{AN} /(\mathrm{PHA}+\mathrm{AN})$ and FIA/ $(\mathrm{FIA}+\mathrm{PY})$ ratios as indicator isomeric values for identification of $\mathrm{PAH}$ origins were $0.48 \pm$ 0.16 and $0.59 \pm 0.22$ respectively.

TABLE II: BIOLOGICAL DETAILS AND $\sum$ PAHS CONCENTRATION OF ANALYZED BIOTA

\begin{tabular}{|c|c|c|c|c|}
\hline Scientific name & English name & Ranges of weight (gr) & Ranges of length (cm) & $\sum$ PAHs \\
\hline Drepane puctata & Sickle fish & $211.6-481$ & $18.5-25.5$ & $21.6 \pm 13.3$ \\
\hline Liza subviridis & Mullet & $28.1-37.6$ & $13.5-16$ & $17.9 \pm 1$ \\
\hline Pumpus argenteus & Silver pomfret & $129-140$ & $17.5-21.6$ & $22.3 \pm 4.3$ \\
\hline Thunnus tongol & Grouper & $289-448$ & $27-32.5$ & $19.9 \pm 13.7$ \\
\hline Thunnus tongol & Longtail tuna & $2400-3800$ & $61-75$ & $19.8 \pm 5.4$ \\
\hline Psettodes erumei & Flounder & $177.7-374.3$ & $25-31.5$ & $24.8 \pm 4.7$ \\
\hline Sardinella albella & Sardine & $20-33.7$ & $13.5-16$ & $19.6 \pm 7.12$ \\
\hline Encrasicholina punctifer & Anchovy & $2-3.44$ & $6.1-8$ & $25.7 \pm 2.4$ \\
\hline Pomadasys kaakan & Grunt & $270.3-371.4$ & $20.7-30.5$ & $16 \pm 8.4$ \\
\hline Lethrinus nebulosus & Sheiri & $244-469$ & $24.6-31.9$ & $16.4 \pm 3.27$ \\
\hline Scomberomorus guttatus & King macrel & $247-459$ & $34.5-46.5$ & $20.23 \pm 10.22$ \\
\hline Otolithes ruber & Tiger tooth croaker & $967-1278$ & $43.4-48.3$ & $16.9 \pm 3.9$ \\
\hline Sillago sihama & Sillago & $21.3-90.4$ & $14-21.5$ & $18.7 \pm 9.1$ \\
\hline Lutjanus johnii & Snapper & $369-509$ & $29-33.5$ & $16.9 \pm 6.4$ \\
\hline Rastrelliger kanagurta & Indian mackerel & $136.7-170.6$ & $23-29.5$ & $21.8 \pm 11.9$ \\
\hline Penaeus mergiensis & Banana shrimp & $8.7-42.3$ & $11.0-16.7$ & $28.18 \pm 3.74$ \\
\hline Portunus segnis & Blue crab & $112-327$ & $11.0-15.5$ & $27.6 \pm 2.42$ \\
\hline Crassostrea gigas & Bivalve & & & $23.6 \pm 12.1$ \\
\hline
\end{tabular}




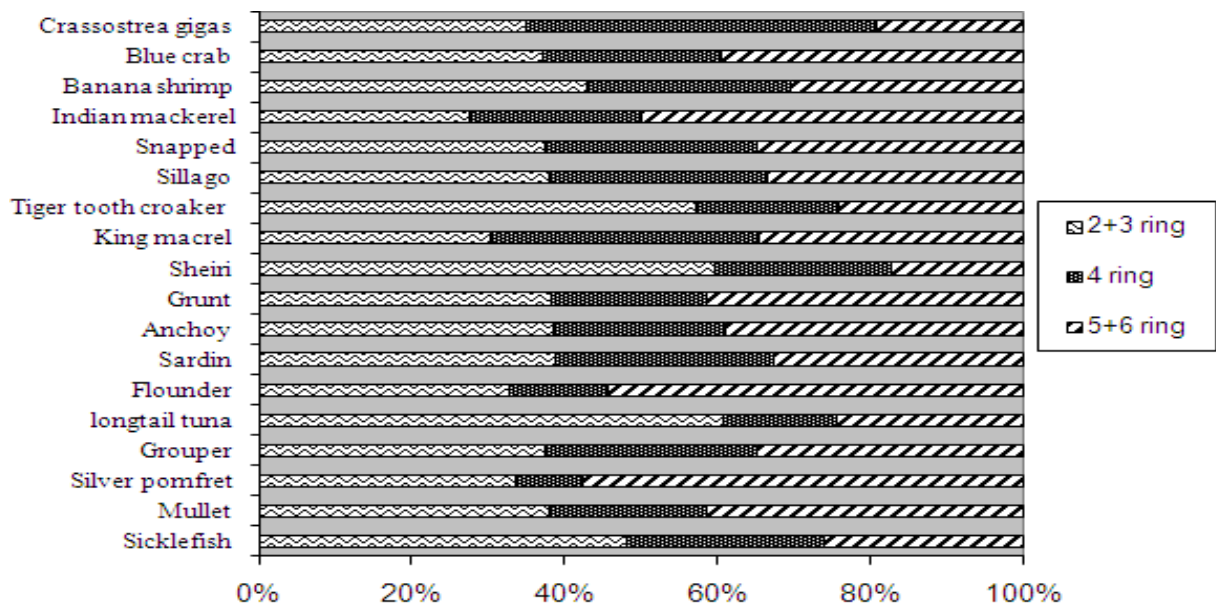

Fig. 1. Percentages of PAHs in fish and seafood from Hormozgan Province

\section{B. Health Risk Assessment}

Among the PAHs components, benzo (a) pyrene and high molecular weight PAHs have an enormous importance in ecotoxicological studies according to their carcinogenic potential [14]. Table III shows the calculated B (a) $\mathrm{P}_{\text {eq }}$ values. The highest values related to Indian mackerel, Silver pomfret and Anchoy. The mean B (a) $\mathrm{P}_{\text {eq }}$ values for studied fish, shrimp, crab and bivalve from Hormozgan Province were $2.87,1.84,2.82$ and $1.1 \mathrm{ng} / \mathrm{g}$ respectively.

TABLE III: B (A) $P_{\text {EO) }}$ VALUes (NG/G) FOR TeSTED SEAFOOD

\begin{tabular}{llll}
\hline \hline Name & Mean \pm SD & Name & Mean \pm SD \\
\hline Sicklefish & $3.08 \pm 2.35$ & Sheiri & $0.37 \pm 0.24$ \\
Mullet & $3.31 \pm 2.6$ & King macrel & $2.02 \pm 2.25$ \\
Silver pomfret & $5.04 \pm 2.58$ & Tiger tooth croaker & $1.42 \pm 2.01$ \\
Grouper & $3.27 \pm 2.8$ & Sillago & $2.84 \pm 2.40$ \\
longtail tuna & $2.35 \pm 3.17$ & Snapped & $0.79 \pm 0.62$ \\
Flounder & $3.43 \pm 2.11$ & Indian mackerel & $6.59 \pm 2.23$ \\
Sardin & $2.93 \pm 2.2$ & Banana shrimp & $1.84 \pm 0.4$ \\
Anchoy & $4.71 \pm 0.37$ & Blue crab & $2.82 \pm 2.02$ \\
Grunt & $0.93 \pm 0.75$ & Bivalve & $1.1 \pm 1.45$ \\
\hline \hline
\end{tabular}

The health risk is assessable through dietary intakes of pollutants. Table IV indicates the means dietary intakes of $\mathrm{BaP}$, seven and eight carcinogenic PAHs.

Hormozgan people receive more of $\mathrm{BaP}$ and PAHs with carcinogenic property through fish consuming, due to higher consuming rate.

Moreover, screening value (SV) is known as an useful tool in risk management. In the established screening value by USEPA, the body weight and consumption rate were supposed as $70 \mathrm{~kg}$ and $142.4 \mathrm{~g} /$ day respectively [11]. These values were different for Hormozgan Province consumers. The calculated screening value for Hormozgan Province population based on local information regarding to body weight and consumption rate was $1.825 \mathrm{ng} / \mathrm{g}$.

The comparison of obtained $\mathrm{B}$ (a) $\mathrm{P}_{\mathrm{eq}}$ values with calculated SVs for consumers of Hormozgan Province showed that except bivalve, the studied seafood contained $\mathrm{B}[\mathrm{a}] \mathrm{P}$ equivalents higher than screening value, offering the intensive need to risk management.

TABLE IV: DiETARy INTAKeS OF PAHS FOR HORMOZGAN PROVINCE URBAN POPULATION

\begin{tabular}{|c|c|c|c|}
\hline PAH & Concentration (ng/g wet wt.) & Consumption rate (g/day/person ) & Mean dietary intake $(\mu /$ day/person $)$ \\
\hline $\mathrm{BaP}$ & 1.63 & & 0.089 \\
\hline \multirow[t]{2}{*}{ sum of eight congeners ${ }^{\mathrm{b}}$} & 9.1 & & 0.5 \\
\hline & & $\underline{\text { Shrimp }}$ & \\
\hline sum of seven congeners & 10.79 & 21.9 & 0.24 \\
\hline \multirow[t]{2}{*}{ sum of eight congeners } & 10.82 & & 0.24 \\
\hline & & $\underline{\text { Crap }}$ & \\
\hline $\mathrm{BaP}$ & 0.28 & & 0.00045 \\
\hline $\mathrm{BaP}$ & 0.56 & & 0.000112 \\
\hline sum of seven congeners & 7.9 & 0.0002 & 0.00158 \\
\hline sum of eight congeners & 7.94 & & 0.001588 \\
\hline
\end{tabular}

${ }^{\text {a }}$ Seven congeners refer to seven congeners with carcinogenic property, including of BaA, CHR, BbF, BkF, BaP, DahA and IcdP. ${ }^{\mathrm{b}}$ Eight congeners refer to eight congeners with carcinogenic property, including of $\mathrm{BaA}, \mathrm{CHR}, \mathrm{BbF}, \mathrm{BkF}, \mathrm{BaP}, \mathrm{DahA}$, IcdP and BghiP. 


\section{DISCUSSION}

According to the $\sum$ PAHs variations and representations of categories in Table V [15], the tested samples were classified as minimally in polluted biota.

TABLE V: CRITERIA FOR PAH CONCENTRATION IN FISH

\begin{tabular}{cc}
\hline \hline Category & PAH concentration $(\mathrm{ng} / \mathrm{g})$ \\
\hline Not contaminated & $<10$ \\
Minimally contaminated & $10-99$ \\
Moderately contaminated & $100-1000$ \\
Highly contaminated & $>1000$ \\
\hline \hline
\end{tabular}

Diagnostic ratios of $\mathrm{AN} /(\mathrm{PHA}+\mathrm{AN})>0.1$ and $\mathrm{FIA} /$ $(\mathrm{FIA}+\mathrm{PY})>0.4$ indicate the pyrogenic origin of $\mathrm{PAH}$ components [16]. The dominate with high molecular weight PAHs and diagnostic ratios confirmed the pyrogenic source of PAH pollution in studied biota. In past two decades, Hormozgan province had a rapid economic and urban expansion. Urban and industrial wastewaters have been discharged in marine environment. Furthermore, high traffic of marine transportations in studied area results to release of PAH with Pyrogenic source. With regard to studies associated with PAH pollution in edible seafood, there are so limited published data, especially in Southern Iran. The detected average value for $\sum$ PAHs in clams from Bushehr Province was $421.86 \mathrm{ng} / \mathrm{g}$, this value is much higher than our result, attributing to species of studied biota and area, because Bushehr is the mail area in Iranian oil export [17]. Sixteen individual PAH components were studied in 2 types of fish from Musa Inlet in the northwest of the Persian Gulf. Molecular ratios showed that in studied area, PAHs have been originated from both pyrogenic and petrogenic sources, however the pyrogenic sources were predominant [18]. In comparison with the international results, our findings were in good agreement with range of $\sum$ PAHs (73-135 ng/ g dry weight) reported for fish from Kuwait [19]. Dietary intakes of PAHs were determined for Kuwaiti people on 2009. $\sum$ PAHs varied from 30 to $247 \mathrm{ng} / \mathrm{g}$ dry weight, whereas the maximum value was detected in fish imported from Iran to Kuwait. Mean dietary intakes of $\mathrm{B}$ (a) $\mathrm{P}_{\text {eq }}$ was reported as $0.00133 \mu \mathrm{g} /$ day [20].

Values of $\sum$ PAHs in mussels from Istanbul Strait and Marmara Sea varied from 43 to $601 \mathrm{ng} / \mathrm{g}$ wet weight and mainly originated from pyrogenic source [4]. $2 \mathrm{PAHs}$ in marine fish samples from Hong Kong markets ranged from 15.5 to $118 \mathrm{ng} / \mathrm{g}$ wet weight, and the petrogenic source was known as the major polluting origin [3]. The concentrations of parent PAHs in bivalves from RSA (ROPME Sea Area) showed the wide range of 2 to $419 \mathrm{ng} / \mathrm{g}$ dry weight, and the maximum level was attributed to oyster from Mina Al Fahal, whereas the fish samples contained the much lower amounts from 0.4 to $13 \mathrm{ng} / \mathrm{g}$ ) [10].

Taiyuan city is one of the most contaminated cities in China, suffers from unjustly planned industrial structure, which causes heavy contamination. $\sum$ PAHs and B (a) $\mathrm{P}_{\text {eq }}$ for fish from Taiyuan city reported as 160 and $5.71 \mathrm{ng} / \mathrm{g}$ wet weight respectively [21] which were much higher than our results.

A comprehensive study was carried in Catalonia, Spain, in order to estimate the PAH intake through various kinds of foods. Dietary intakes of Benzo[a] pyrene, $\sum$ seven and Seight carcinogenic PAHs were 0.003, 0.026, and 0. 029 $\mu \mathrm{g} /$ day, respectively for adult men [14]. The calculated values for people from Hormozgan Province were much higher than for Spanish. The total intake of B (a)P was estimated at $0.15 \mu \mathrm{g} / \mathrm{d} /$ person for fish from Red Sea coat of Yeman which was higher than ours [5].

\section{CONCLUSION}

According to undesired biological effects of PAHs, there is a special concern about their health risk assessment. Unfortunately, there was no data on human risk assessment from PAHs in Iran. The $\sum$ PAHs concentrations in collected biota showed that PAH contamination in fish and seafood from Hormozgan Province were relatively high. The worry would be more serious when PAHs with high molecular weight dominate to light ones. The risk of poly aromatic hydrocarbons intake through fish consuming was noticeable. However, for final risk assessment of PAHs, more investigations on the contribution of other food groups (meat products, oil and fats, fruits and vegetables), cooking methods and rate consuming of various food categories with regards to sex and age are suggested. Risk management has to apply in order to support the health of consumers in Hormozgan Province. Control and environmental management of urban and industrial discharges have not been ignored.

\section{ACKNOWLEDGMENT}

The staffs of Persian Gulf and Oman Sea Ecological Research Institute are gratefully acknowledged for providing the sample collection and analysis facilities. We mostly extend our sincere gratitude to Mr. Chantal Cattini from Marine Environmental Laboratories, International Atomic Energy Agency for scientific guidance.

\section{REFERENCES}

[1] M. D. Erickson, Analytical chemistry of PCBs; New York: CRC, 1997, h.2.

[2] P. Zhang, J. Song, and H. Yuan, "Persistent organic pollutant residues in the sediments and mollusks from the Bohai Sea coastal areas, North China: An overview," Environment international, vol. 35, no. 3, pp. 632-646, December, 2009.

[3] K. Cheung et al., "Residual levels of DDTs and PAHs in freshwater and marine fish from Hong Kong markets and their health risk assessment, "Chemosphere, vol. 66, no. 3, pp. $460-468,2007$.

[4] B. Karacik, O. S. Okay, B. Henkelman, S. Bernhöft, and K. W. Schramm, "Polycyclic aromatic hydrocarbons and effects on marine organisms in the Istanbul Strait," Environment international, vol. 35, no. 3, pp. 599-606, January 2009.

[5] A. A. Z. Dou Abul, H. M. A. Heba, and K. H. Fareed, "Polynuclear aromatic hydrocarbons (PAHs) in fish from the Red Sea Coast of Yemen," Hydrobiologia, vol. 352, pp. 251-262, March1997.

[6] C. Anyakora and H. Coker, "Assessment of polynuclear aromatic hydrocarbon content in four species of fish in the Niger Delta by gas chromatography/mass spectrometry, " African Journal of Biotechnology, vol.6, no. 6, pp. 737-743, March 2007.

[7] C. Anyakora, A. Ogbeche, P. Palmer, and H. Coker, "Determination of polynuclear aromatic hydrocarbons in marine samples of Siokolo Fishing Settlement," Journal of chromatography A, vol.1073, pp. 323-330, 2005.

[8] R. Simon, S. Palme, and E. Anklam, "Single-laboratory validation of a gas chromatography-mass spectrometry method for quantitation of 15 European priority polycyclic aromatic hydrocarbons in spiked 
smoke flavourings," Journal of chromatography A, vol.1103, pp. 307-313, 2006

[9] O. Pelkonen and D.W. Nebert, "Metabolism of polycyclic aromatic hydrocarbons: etiologic role in carcinogenesis," Pharmacological reviews, vol.34, no. 2, pp. 189-222, 1982.

[10] S. De Mora et al., "Distribution of petroleum hydrocarbons and organochlorinated contaminants in marine biota and coastal sediments from the ROPME Sea Area during 2005," Marine Pollution Bulletin, vol. 60, no. 12, pp. 2323-2349, 2010.

[11] U. S. Environmental Protection Agency, "Guidance for assessing chemical contaminant data for use in fish advisories-Fish sampling and analysis," vol. 1, $3^{\text {rd }}$ ed, (EPA823-R-B-00-007). Office of Water, Washington, DC, 2000a.

[12] I. C. T. Nisbet and P. K. LaGoy, "Toxic equivalency factors (TEFs) for polycyclic aromatic hydrocarbons (PAHs)," Regulatory Toxicology and Pharmacology, vol. 16, pp. 290-300, 1992.

[13] A. Bocio, J. L. Doming, G. Falco, and J. M. Llobet, "Concentrations of PCDD/PCDFs and PCBs in fish and seafood from the Catalan (Spain) market: estimated human intake," Environment international, vol. 33 , pp. $170-175,2007$

[14] I. Martorell et al., "Polycyclic aromatic hydrocarbons (PAH) in foods and estimated PAH intake by the population of Catalonia, Spain: Temporal trend," Environment international, vol. 36, pp. 424-432, April 2010.

[15] A. Soares-Gomes et al., "Changes and variations of polycyclic aromatic hydrocarbon concentrations in fish, barnacles and crabs following an oil spill in a mangrove of Guanabara Bay, Southeast Brazil," Marine Pollution Bulletin, vol. 60, pp. 1359-1363, 2010.

[16] Y. Liu, L. Chen, Q. Huang, W. Li, and J. Zhao, "Source apportionment of polycyclic aromatic hydrocarbons (PAHs) in surface sediments of the Huangpu River, Shanghai, China," Science of the Total Environment, vol. 407, pp. 2931-2938, 2009.

[17] A. Safahieh, M. Mahmoodi, Y. Nikpoor, and K. Ghanemi, "PAHs Concentration in Ark clam (Barbatia helblingii) From South Persian Gulf, Bushehr, Iran,” International Journal of Environmental and Development, vol. 2, PP. 394-398, October 2011.

[18] M. Hasanati, A. Savari, Y. Nikpoor, and K. Ghanemi, "Assessment of the Sources of Polycyclic Aromatic Hydrocarbons in Mousa Inlet by Molecular Ratios," Journal of Environmental Studies, vol. 37, PP.1-3, Desember.

[19] Al-Yakoob, T. Saeed, and H. Al-Hashash, "Polycyclic aromatic hydrocarbons in edible tissue of fish from the Gulf after the 1991 oil spill, "Marine Pollution Bulletin, vol. 27, pp. 297-301, 1993.

[20] H. Alomirah et al., "Dietary exposure to polycyclic aromatic hydrocarbons from commercially important seafood of the Arabian Gulf," Journal of Food, Agriculture \& Environment, vol.7, PP.9-15, 2009.
[21] Z. Xia et al., "Health risk assessment on dietary exposure to polycyclic aromatic hydrocarbons (PAHs) in Taiyuan, China," Science of the Total Environment, , vol. 408, pp. 5331-5337, Agust 2010.

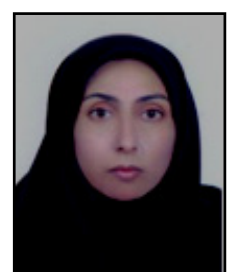

S. L. Mohebbi Nozar was born on 5 March 1970 in Kuwait. She obtained B.sc degree (pure chemistry) from Shahid Bahonar University and M.Sc degree (organic chemistry) from Tarbiat Moallem University of Tehran. Now, she is a ph.D student at Universiti Sains Malaysia (USM).

She is an academic member of Iranian agriculture research, education \& extension organization. Her Persian Gulf and Oman Sea. interested field research is the organic pollution in

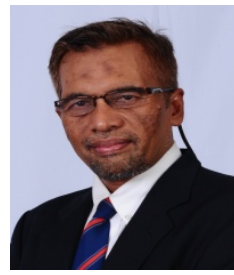

Wan Ruslan Ismail was born in Perlis, Malaysia on the 27 January 1960 . He graduated with a BSc. (Hons) in Meteorology and Oceanography in 1984 from Plymouth Polytechnics, UK; a MSc in Oceanography from the University of Southampton in 1987 and $\mathrm{PhD}$ in Hydrology from the University of Manchester in 1996. His main interest since joining the department was in catchment hydrology, geomorphology, soil erosion and sediment yields, wetlands, lakes and reservoirs sedimentation. Currently he is involved with studying sediment and nutrient input into estuaries; lakes and reservoirs and previous research interests include studying hydrology, soil erosion and sediment yield and water quality of tropical rivers.

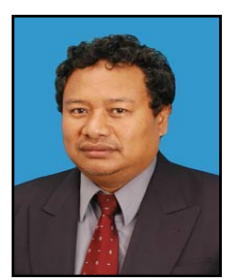

Mohamad Pauzi Zakaria was born on 25 September 1957. He completed his PhD degree in Environmental Organic Geochemistry from Tokyo University of Agriculture and Technology Tokyo, Japan. Now, He is Professor of Environmental science, Faculty of Environmental Studies, Universiti Putra Malaysia (UPM) and he has been a Guest Professor of FOLENS, Tokyo University of Agriculture and Technology (TUAT). He served on several international conferences as Paper Reviewer, Expert Panel Member and Scientific Advisory. He has published more than 70 journal articles and books in environmental science and pollution and finished 6 projects as a leader from 2006 to 2012. Prof. Dr. M.P. Zakaria is presently Deputy Dean (Postgraduate, Research and Development), Faculty of Environmental Studies, Universiti Putra Malaysia and Associate Researcher, Laboratory of Marine Science and Aquaculture (MARSLAB), Institute of Bioscience, UPM. He won several international and national scientific awards. 